\title{
NOVEL USE OF THE INTEL REALSENSE SR300 CAMERA FOR FOOT 3D RECONSTRUCTION
}

\author{
Fangchuan $\mathrm{LI}^{1}$, Shuangjia $\mathrm{LIU}^{1}$, Luyu JIANG ${ }^{1}$, Weihua ZHANG ${ }^{2}$, Jin $\mathrm{ZHOU}^{3 *}$ \\ ${ }^{1}$ College of Software Engineering, Sichuan University; Chengdu 610065, P. R. China \\ ${ }^{2}$ College of Computer Science, Sichuan University; Chengdu 610065, P. R. China
}

${ }^{3}$ The Key Laboratory of Leather Chemistry and Engineering Ministry of Education, Sichuan University; Chengdu 610065, P. R. China

\section{NOVEL USE OF THE INTEL REALSENSE SR300 CAMERA FOR FOOT 3D RECONSTRUCTION}

ABSTRACT. Foot three-dimensional (3D) reconstruction is increasingly used in real life at present; however, current 3D measuring devices are usually expensive and have a large volume. So they are limited used in a specific domain and feasible method for accurate, fast and low-cost foot 3D reconstruction are required. Since the Intel RealSense SR300 camera has advantages on 3D scanning, such as high efficiency, portable, low-cost and simple operation, this camera has been widely applied in multi-scenario, such as gaming. But its performance on foot scanning is still unknown. Thereby this study first aimed to design and develop a foot 3D scanning protocol based on the Intel RealSense SR300 camera and then to contrast this new method with a traditional one in terms of accuracy. Fifteen healthy adults without any foot deformity or foot disease participated and their feet were measured by our simulated measurements (SM) and manual measurements (MM). 13 variables were calculated and contrasted and their significant differences were assessed by Single-Sample T Test with significant level of 0.05 and confident interval of $95 \%$. The results show that the SR300 presented a precise foot 3D reconstruction on the mean differences ranged from $-1.3 \mathrm{~mm}$ to $5.2 \mathrm{~mm}$; meanwhile eight of the thirteen foot parameters exhibited no significant differences between the two methods. Overall, these findings above demonstrate that the SR300 is a valid tool for foot 3D scanning and it can be widely applied in the both medical and commercial fields.

KEY WORDS: Intel RealSense SR300, foot 3D scanning, foot measurement, footwear customization

\section{UTILIZARE NOUĂ A CAMEREI INTEL REALSENSE SR300 PENTRU RECONSTRUCȚIA 3D A PICIORULUI}

REZUMAT. Reconstituirea tridimensională (3D) a piciorului este folosită din ce în ce mai mult în viața reală în prezent; cu toate acestea, dispozitivele de măsurare 3D actuale sunt de obicei costisitoare și au un volum mare. Așadar utilizarea este limitată la un anumit domeniu și este necesară o metodă fezabilă pentru o reconstrucție 3D a piciorului exactă, rapidă și cu costuri reduse. Întrucât camera Intel RealSense SR300 are avantaje în ceea ce privește scanarea 3D, cum ar fi eficiență ridicată, portabilitate, costuri reduse și operare simplă, această cameră a fost aplicată pe scară largă în mai multe domenii, cum ar fi jocurile. Însă performanțele acesteia la scanarea piciorului nu sunt cunoscute încă. Prin urmare, acest studiu a avut ca scop mai întâi de a proiecta și dezvolta un protocol de scanare 3D pentru picioare bazat pe camera Intel RealSense SR300 și apoi de a compara această nouă metodă cu una tradițională din punctul de vedere al preciziei. La studiu au participat cincisprezece adulți sănătoși fără deformări sau boli ale piciorului, efectuându-se măsurători simulate (SM) și măsurători manuale (MM) ale piciorului. S-au calculat și comparat 13 variabile, iar diferențele semnificative ale acestora au fost evaluate prin testul T cu un singur eșantion, cu un nivel de semnificație de 0,05 și un interval de încredere de $95 \%$. Rezultatele arată că SR300 a prezentat o reconstrucție 3D precisă a piciorului, diferențele medii fiind cuprinse între $-1,3 \mathrm{~mm}$ și $5,2 \mathrm{~mm}$; pe de altă parte, opt dintre cei treisprezece parametri ai piciorului nu au prezentat diferențe semnificative între cele două metode. În general, aceste concluzii de mai sus demonstrează că SR300 este un instrument valid pentru scanarea 3D a picioarelor și poate fi aplicat pe scară largă atât în domeniul medical cât și în cel comercial.

CUVINTE CHEIE: Intel RealSense SR300, scanare 3D a piciorului, măsurarea piciorului, personalizarea încălțămintei

\section{UNE NOUVELLE UTILISATION DE LA CAMÉRA INTEL REALSENSE SR300 POUR LA RECONSTRUCTION 3D DU PIED}

RÉSUMÉ. La reconstruction tridimensionnelle (3D) du pied est de plus en plus utilisée dans la vie réelle à l'heure actuelle ; cependant, les appareils de mesure 3D actuels sont généralement chers et ont un grand volume. Ils sont donc limités dans un domaine spécifique et une méthode réalisable pour une reconstruction 3D précise, rapide et peu coûteuse du pied est requise. Étant donné que la caméra Intel RealSense SR300 présente des avantages sur la numérisation 3D, tels qu'une efficacité élevée, un fonctionnement portable, peu coûteux et simple, cette caméra a été largement appliquée dans plusieurs scénarios, tels que les jeux. Mais les performances sur le balayage des pieds sont encore inconnues. Ainsi, cette étude visait d'abord à concevoir et à développer un protocole de numérisation 3D du pied basé sur la caméra Intel RealSense SR300, puis à comparer cette nouvelle méthode avec une méthode traditionnelle en termes de précision. Quinze adultes en bonne santé sans aucune déformation du pied ou maladie du pied ont participé et on a fait de mesures simulées (SM) et mesures manuelles (MM) sur leurs pieds. On a calculé et comparé 13 variables et leurs différences significatives ont été évaluées par le test Tà échantillon unique avec un niveau de signification de 0,05 et un intervalle de confiance de $95 \%$. Les résultats montrent que le SR300 présentait une reconstruction 3D précise du pied avec des différences moyennes variant de $-1,3 \mathrm{~mm}$ à $5,2 \mathrm{~mm}$; d'autre part, huit des treize paramètres du pied ne présentaient aucune différence significative entre les deux méthodes. Dans l'ensemble, ces résultats ci-dessus démontrent que le SR300 est un outil valide pour la numérisation 3D du pied et qu'il peut être largement appliqué dans les domaines médical et commercial. MOTS CLÉS : Intel RealSense SR300, numérisation 3D du pied, mesure des pieds, personnalisation des chaussures

\footnotetext{
* Correspondence to: Assoc. Prof. Dr. Jin ZHOU, College of Biomass Science and Engineering, Sichuan University; Chengdu 610065, P. R. China, zj_scu@scu.edu.cn
} 


\section{INTRODUCTION}

With the development of computer vision, virtual reality technology has been applied to various fields of life, including aerospace, manufacturing, reverse engineering and medical treatment, etc. While, 3D model reconstruction is one of key technologies in field of virtual reality and it has been intensively concerned by researchers $[1,2]$.

In shoe-making industry, accurate, fast and low-cost 3D scanning protocol is required for foot measurements. Different from the manual measurement, it provides a standard process and obtains consistent outcomes. At present, the mainstream technology of $3 \mathrm{D}$ reconstruction includes scanning technology $[3,4]$, structure from motion technology [5], and reverse mould technology, etc. However, in the past studies, the equipment commonly features the large volume, high price, long scanning time, and higher technical requirements upon the operators. For example, Menato et al. [6] obtained the foot 3D model through a self-developed 3D scanning App on the smartphone platform, although its precision reaches $0.15 \mathrm{~mm}$, the time-consuming of creating foot 3D model is nearly 15 minutes. Novak et al. [7] used four charge-coupled device cameras to wrap around participants' feet and scan with a laser line, requiring a huge and inconvenient walking stage with $4.7 \mathrm{~m}$ long and $0.8 \mathrm{~m}$ wide. Further, Gao et al. [8] used an active marking method, in which the participants wore socks with markers, and used 10 CCD cameras to capture video of foot movements; this method has complex experiment procedures with a series of operations, and it's hard to apply in real life. As shown above, most high-quality foot scanners are implausible regarding application. Hence, as an emerging depth camera, the Intel RealSense SR300 camera is a good tool which balancing convenience in use, clarity in visualization and accuracy in outcomes.

The SR300 may simultaneously capture the color, depth and other image information widely admitted in the real scenario, such as face direction recognition [9], robotic technology [10], gesture recognition [11], 3D model reconstruction, human body rehabilitation [12], and etc. As a result, we assumed whether this camera could be used in foot 3D scanning. Therefore, the objectives of this study were set as follows: 1 . to develop a foot 3D reconstruction method with the Intel RealSense SR300 camera; 2. to compare the result obtained in the new method with a traditional one to verify its accuracy.

\section{EXPERIMENTAL}

\section{Methods}

\section{Participants}

Fifteen students (gender $=11$ males, 4 females; height $=1.73 \pm 0.14 \mathrm{~m}$; body mass $=$ $65.20 \pm 18.20 \mathrm{~kg}$ ) from the Sichuan University were invited to this study. None of them had any types of foot deformities or foot diseases. All participants gave written informed consent before participation in this study.

\section{Manual Foot Measurements (MM)}

The methods used were in accordance with the guidelines developed by the research committee of Sichuan University. Before measuring, all participants' feet were disinfected and dried. Participants sat on stools and put their right legs horizontally on other ones. The operator measured thirteen foot parameters on each participant's right foot using a tape measure and a straightedge. There were three trials of MM for each foot parameter. All foot parameter definitions are as shown in Table 2 and the foot coordinate system we established is provided in Figure 2.

\section{Simulated Foot Measurements (SM)}

The foot scanner (Figure 1) adopted the Intel RealSense SR300 camera as the core hardware equipment, while the SR300 is a shortdistance light coding 3D imaging camera [1315]. We adopted the Visual Studio 2015 as the development platform and the Intel RealSense SDK 2016 R2 as our 3D scanning component library $[9,16]$. All configuration parameters of SR300 are shown in Table 1 . The main theory of the Intel RealSense SR300 camera is shown below: during the 3D scanning, the SR300 emits the specific "structured light" to the object surface via the infrared laser projector, which will be accepted by the high-speed VGA Infrared 
Camera after the object reflection. Due to the variable distances from the infrared ray to the object surface, the distances and locations of "structured light" captured by the Infrared
Camera may vary [17]. It is feasible to calculate the space information on the object surface, and further restore the whole 3D space.

Table 1: Intel RealSense SR300 camera configuration parameters

\begin{tabular}{cc}
\hline Configuration & Parameters \\
\hline Scanning Mode & HEAD \\
Scanning Range & $40 \mathrm{~cm} \sim 60 \mathrm{~cm}$ \\
Reconstruction Option & TEXTURE and SOLIDIFICATION \\
Max Triangles & 0 (no limitation) \\
Max Vertices & 0 (no limitation) \\
Max Texture Resolution Width & 1920 \\
Max Texture Resolution Height & 1080 \\
Flop Preview Image & False \\
Use Marker & False \\
File Format & OBJ \\
\hline
\end{tabular}

The foot scanner was mounted flush with the laboratory floor, and away from outside and windows, sunlight includes infrared light which may interfere with the depth imaging system; then we placed multiple diffuse lights around the foot scanner to improve the uniformity of the illumination and to avoid a too dark or corrupt scan color; besides, participants were asked to take off all foot ornaments before scanning, shiny or translucent portions of ornaments may corrupt the scan surface. Participants sat on stools about $70 \mathrm{~cm}$ high and placed their right lower legs on the foot supporter in range of $40 \mathrm{~cm}$ to $60 \mathrm{~cm}$ from the Intel RealSense SR300 camera, the point cloud out of this range were automatically subtracted in head scanning mode (Table 1). They were instructed to remain as still as possible for the period of the SR300 scanning. Each foot was scanned for 50 seconds. A total of two successful trials were conducted for each participant and the foot scanner with 30 seconds of rest between trials and 2 minutes between each participant.

The following steps conducted for every frame of foot depth data during the working process: firstly, the foot depth data was transformed into the floating point cloud in meters; secondly, the bilateral filtering was used to carry out the denoising upon the depth floating point cloud, which could keep smooth at the edge; thirdly, the floating point cloud of plane-coordinate system were mapped into the SR300 camera coordinate system; finally, the point cloud of the SR300 camera coordinate system were restored into the global coordinate system. The whole working process for foot 3D reconstruction is shown in Figure 3.

The foot 3D reconstruction data exported from the foot scanner in the obj file format accompanied with an OBJ Material file (.mtl) and a texture map file (.png). We imported these files in meters into software 3D Builder (V18, Microsoft, USA) and used the spilt function in software to cut the excessive part (foot supporter, etc) of the point cloud; then meshed the point cloud; afterwards, the texture mapping technology was used to render the foot point cloud mesh. We manually measured thirteen foot parameters (Table 2) on the 3D foot model using the measuring tool in software. There were also three trials of SM for each foot parameter.

\section{Data Processing and Statistical Analysis}

The outcomes used in this study were MM and SM. The differences between them were chosen as the primary value to verify foot 3D model accuracy because of its widely recognized effectiveness in foot measurements assessment [18]. To avoid potential errors, we used the averaged value with standard deviation for each parameter. Meanwhile, the significant differences were assessed by Single-Sample $T$ 
Test (HO: there are no significant differences between the two groups). All statistical analyses were operated under software SPSS (V21, IBM, USA) with significant level of 0.05 and confidence interval of $95 \%$.

Table 2: Foot measurement parameter definitions

\begin{tabular}{|c|c|}
\hline Location & Parameter definition \\
\hline Foot length & Distance from pternion to acropodion \\
\hline Foot width & Maximum width in parallel with the $x$-axis \\
\hline Arch length & Distance from pternion to toe root on the $y$-axis \\
\hline Waist girth & The distance around the circumference of the foot from foot length center \\
\hline Ball girth & The distance around the circumference of the foot from toe root \\
\hline Heel width & The width measured from the pternion at the $40 \mathrm{~mm}$ along the $y$-axis and in parallel with the $x$-axis \\
\hline Heel to the fifth toe & Distance measured from the heel to the fifth toe in parallel with the $y$-axis \\
\hline Medial malleolus height & Distance of medial malleolus on the $z$-axis \\
\hline Lateral malleolus height & Distance of lateral malleolus on the z-axis \\
\hline Bimalleolar width & Distance of medial malleolus and lateral malleolus on the $x$-axis \\
\hline Ankle girth & Horizontal girth at the foot and leg intersection \\
\hline Heel to the medial malleolus & Distance from pternion to medial malleolus at the $x O y$ mapping point on the $y$-axis \\
\hline Heel to the lateral malleolus & Distance from pternion to lateral malleolus at the xOy mapping point on the $y$-axis \\
\hline
\end{tabular}

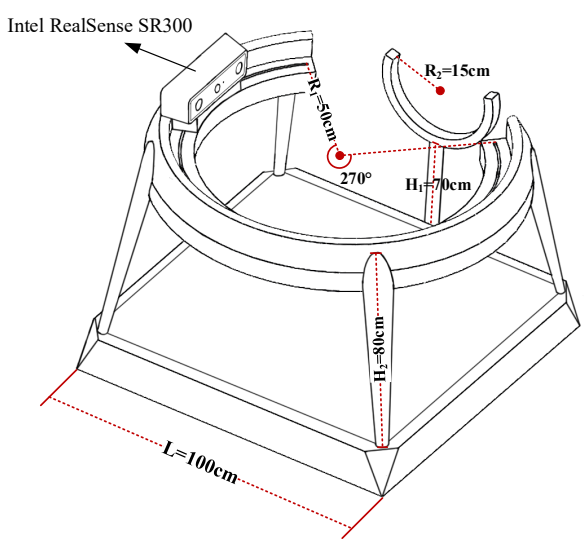

Figure 1. The self-developed foot scanner base on the Intel RealSense SR300 camera
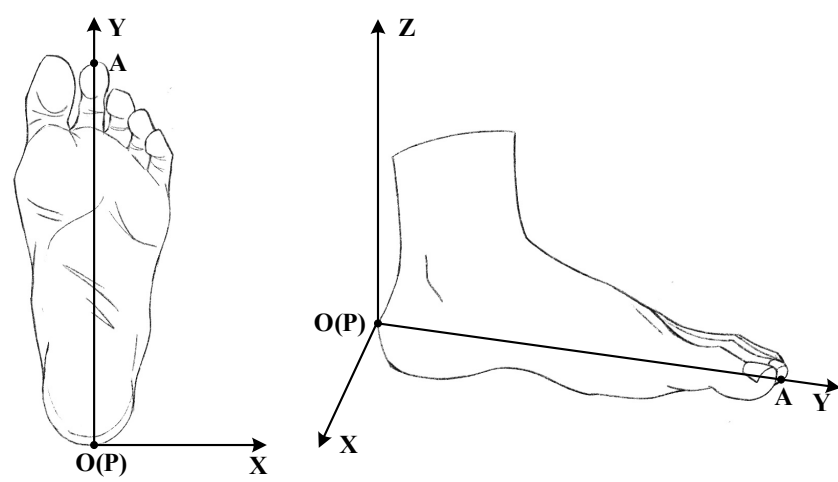

Figure 2. Foot coordinate system 


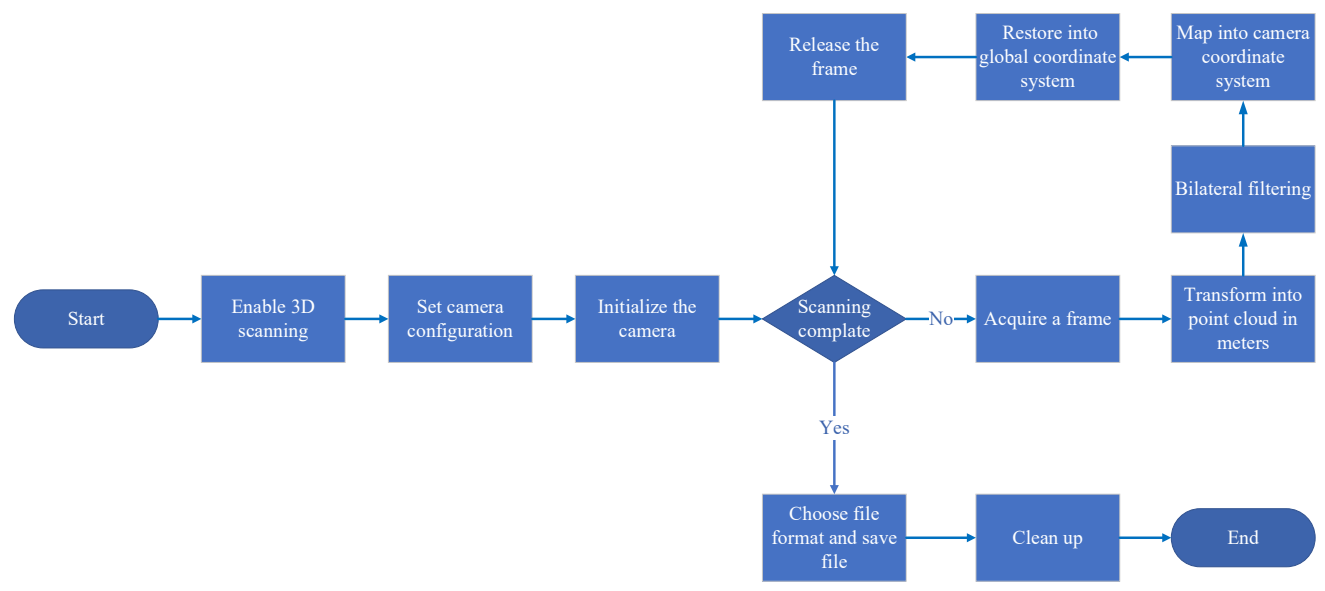

Figure 3. Foot 3D reconstruction working process flowchart

\section{RESULTS}

Table 3 shows a foot 3D reconstruction result of one of the male participants with four various angles and in two styles (meshed and rendered images).

Descriptive statistics and differences of the thirteen foot parameters measurements obtained from the two methods are given in Tables 4 . It can be seen that the maximum mean difference was $5.2 \mathrm{~mm}$ between the
MM and the SM. Only the performance on the measurements of arch length and ankle girth had the mean differences greater than $3.0 \mathrm{~mm}$, other measurements had the value of mean differences between $-1.3 \mathrm{~mm}$ and $1.2 \mathrm{~mm}$. Statistical analyses showed that the performance on the measurements of arch length, medial malleolus height, lateral malleolus height, ankle girth and heel to medial malleolus failing to reach an $P$ value of 0.05 .

Table 3: An overview of foot 3D reconstruction

Location


Medial malleolus side
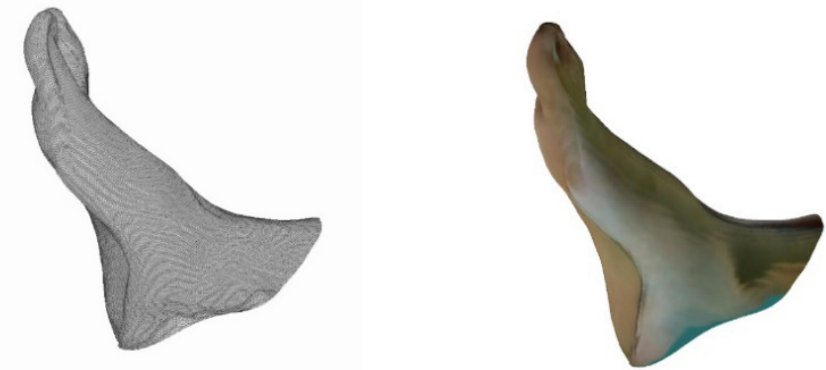

Lateral malleolus side
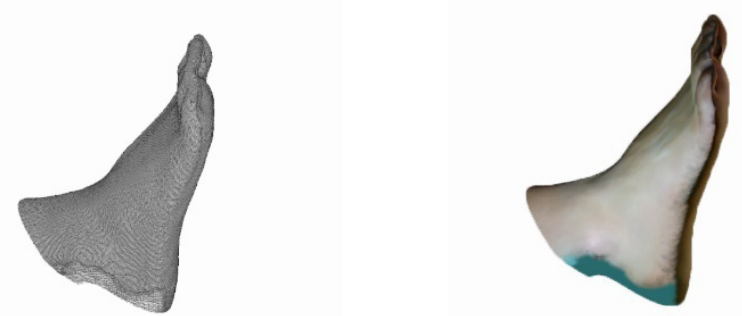

Table 4: Descriptive statistics and differences of thirteen foot parameters from the two methods

\begin{tabular}{cccccccc}
\hline \multirow{2}{*}{ Foot measurement } & \multicolumn{2}{c}{ MM } & \multicolumn{2}{c}{ SM } & \multicolumn{3}{c}{ Differences } \\
& Mean & Std. dev. & Mean & Std. dev. & Mean & Std. dev. & $\begin{array}{c}\text { P-value (H0: } \\
\text { mean }=0)\end{array}$ \\
\hline Foot length & 259.0 & 11.4 & 259.0 & 12.2 & -0.1 & 2.7 & 0.986 \\
Foot width & 93.1 & 3.4 & 93.2 & 3.7 & -0.1 & 1.1 & 0.818 \\
Arch length & 190.1 & 6.8 & 186.2 & 7.6 & 3.8 & 3.1 & $<0.001$ \\
Waist girth & 237.7 & 13.1 & 236.5 & 14.2 & 1.2 & 4.0 & 0.280 \\
Ball girth & 231.0 & 6.8 & 230.6 & 6.7 & 0.5 & 2.1 & 0.443 \\
Heel width & 69.1 & 4.8 & 69.5 & 5.7 & -0.4 & 2.3 & 0.506 \\
Heel to the fifth toe & 209.0 & 10.8 & 209.8 & 9.6 & -0.8 & 3.1 & 0.377 \\
Medial malleolus height & 84.1 & 3.3 & 83.6 & 3.2 & 0.4 & 0.4 & 0.001 \\
Lateral malleolus height & 73.5 & 5.1 & 74.7 & 3.6 & -1.2 & 1.9 & 0.048 \\
Bimalleolar width & 77.6 & 5.0 & 77.3 & 4.9 & 0.3 & 1.4 & 0.489 \\
Ankle girth & 256.7 & 11.3 & 251.5 & 13.8 & 5.2 & 3.6 & $<0.001$ \\
Heel to medial malleolus & 68.0 & 5.6 & 69.3 & 5.4 & -1.3 & 2.7 & 0.006 \\
Heel to lateral malleolus & 60.7 & 4.2 & 60.8 & 3.1 & -0.1 & 1.4 & 0.803 \\
\hline
\end{tabular}

\section{DISCUSSION}

The purpose of our study was to evaluate the performance of the Intel RealSense SR300 camera in foot 3D reconstruction. Comparing MM with SM, we have shown that the SR300 exhibits excellent performance for foot 3D reconstruction and possesses concurrent accuracy with the manual method in traditional foot measurements. Meanwhile, it dramatically shortens the 3D reconstruction time, achieves consistent outcomes and performs a higher robustness.
Although the P-value in Table 4 showed that the two methods had no significant differences in the major 8 parameters, other five foot parameters were reported with significant differences. However, most of the mean differences were smaller than the foot differences in sensitivity (the shoe last size difference that people can feel, generally $6 \mathrm{~mm}$ for men and $2.08 \mathrm{~mm}$ for women [19]). We suggested that those significant differences might be attributed to two main reasons: smooth denoising and solidification. Smooth denoising upon the depth 
image was used in filtering process which might lead to the most medially prominent point offset to an unreal location in the malleolus side measurements; meanwhile, for closed foot 3D model, we executed solidification orders, but it extends the surface curvature to fill the holes in foot 3D model surface.

The foot 3D reconstruction base on SR300 has fast, accurate and low-cost features. Therefore, this device may be put into use in the hospital, public community, and other places in large numbers, through foot 3D reconstruction made upon the feet of a large scale of population, a significant number of foot data may be obtained. Thereby, it may be prepared as per the foot big data, and the statistical analysis may be made in combination with the personal wear comfort data.

Although the current research results are promising, limitations existed and should be declared: firstly, the foot should be kept as still as possible while scanning and it might be difficult for children; secondly, rotational motion range of the SR300 on the foot scanner is $270^{\circ}$ circumference, it is hard to obtain the front color and depth images of the acrotarsium side; thirdly, 3D model reconstruction is realized through the Color Camera and the Infrared Camera, it is required to obtain the color information and the depth information in the real space simultaneously $[20,21]$.

\section{CONCLUSION}

Overall, we approved that the Intel RealSense SR300 camera is a fast, accurate, and low-cost foot scanning protocol, with respect to the manual foot measurements protocol. We explored limitations and constraints may affect the foot 3D reconstruction result of the SR300. We also anticipated that it is likely to build a bridge between laboratory testing and practical application and can be widely applied in the both medical and commercial fields.

\section{Acknowledgements}

Thanks to the Support of the National Natural Science Foundation (31700813).

\section{REFERENCES}

1. Mu, G., Liao, M., Yang, R., Ouyang, D., Xu, Z., Guo, X., Complete 3D model reconstruction using a depth sensor, Proceedings of International Conference on Intelligent Computing and Integrated Systems, Guilin, 2010, 175-179.

2. Zheng, M., Zhu, J., Xiong, X., Zhou, S., Zhang, Y., 3D model reconstruction with common hand-held cameras, Virtual Real, 2016, 20, 4, 221-235, https://doi.org/10.1007/s10055016-0297-5.

3. Shih, N.-J., Kuo, H.-C., Chang, C.-F., 3D scan for special urban evening occasion, 2016 International Conference on Applied System Innovation (ICASI), 2016, 1-4, https://doi. org/10.1109/ICASI.2016.7539742.

4. Nowak, P. S., Sankowski, W., Krotewicz, P., 3D face and hand scans acquisition system dedicated for multimodal biometric identification, 2016 MIXDES23rd International Conference Mixed Design of Integrated Circuits and Systems, 2016, 389-393, https://doi.org/10.1109/ MIXDES.2016.7529772.

5. Laksono, D., Open source stack for Structure from Motion 3D reconstruction: A geometric overview, The 6th International Annual Engineering Seminar (InAES), 2016, 196-201.

6. Menato, S., Landolfi, G., Alge, M., Sorlini, M., Empowering widespread shoe personalization via a 3D foot scanning App, 2014 International Conference on Engineering, Technology and Innovation (ICE), 2014, 1-7, https://doi. org/10.1109/ICE.2014.6871556.

7. Novak, B., Možina, J., Jezeršek, M., 3D laser measurements of bare and shod feet during walking, Gait Posture, 2014, 40, 1, 87-93, https://doi.org/10.1016/j. gaitpost.2014.02.015.

8. Gao, F., Wang, Q., Geng, W., Pan, Y., Acquisition of time-varying 3D foot shapes from video, Science China Information Sciences, 2011, 54, 11, 2256, https://doi.org/10.1007/s11432011-4361-1.

9. Yamashita, T., Yamashita, Y., Masuda, S., Sato-Shimokawara, E., Yamaguchi, T., Face direction recognition system for robot control 
system using fingertip gesture, 2017 IEEE/ SICE International Symposium on System Integration (SII), 2017, 980-985, https://doi. org/10.1109/SII.2017.8279350.

10. Song, K.-T., Chang, Y.-H., Chen, J.-H., 3D Vision for Object Grasp and Obstacle Avoidance of a Collaborative Robot, 2019 IEEE/ASME International Conference on Advanced Intelligent Mechatronics (AIM), 2019, 254-258, https://doi.org/10.1109/ AIM.2019.8868694.

11. Liao, B., Li, J., Ju, Z., Ouyang, G., Hand gesture recognition with generalized hough transform and DC-CNN using realsense, 2018 Eighth International Conference on Information Science and Technology (ICIST), 2018, 84-90, https://doi.org/10.1109/ ICIST.2018.8426125.

12. Zhang, M., Liang, J., Liu, L., Liang, Y., Wang, $X$., Denoising method of body scanning point cloud obtained by SR300, J Cent South Univ, 2018, 49, 9, 2225-2231.

13. Siena, F.L., Byrom, B., Watts, P., Breedon, P., Utilising the Intel RealSense camera for measuring health outcomes in clinical research, J Med Syst, 2018, 42, 3, 53, https:// doi.org/10.1007/s10916-018-0905-x.

14. Carfagni, M., Furferi, R., Governi, L., Servi, M., Uccheddu, F., Volpe, Y., On the performance of the Intel SR300 depth camera: metrological and critical characterization, IEEE Sens J, 2017, 17, 14, 4508-4519, https://doi.org/10.1109/ JSEN.2017.2703829.

15. Zabatani, A., Surazhsky, V., Sperling, E., Ben Moshe, S., Menashe, O., Silver, D.H., Karni, T., Bronstein, A.M., Bronstein, M.M., Kimmel, R., Intel ${ }^{\circledR}$ RealSense ${ }^{\mathrm{TM}}$ SR300 Coded light depth Camera, IEEE Trans Pattern Anal Mach Intell, 2019, http://doi.org/10.1109/ TPAMI.2019.2915841 (Early Access).
16. Patil, J.V., Bailke, P., Real time facial expression recognition using RealSense camera and ANN, 2016 International Conference on Inventive Computation Technologies (ICICT), 2016, vol. 2, 1-6, https://doi.org/10.1109/ INVENTIVE.2016.7824820.

17. Wang, L., Xu, W., Du, K., Lu, W., Zhu, J., Zhang, J., Portabella Mushrooms Measurement in Situ Based on SR300 Depth Camera, Transactions of The Chinese Society of Agricultural Machinery, 2018, 49, 12, 13-19.

18. Witana, C.P., Xiong, S., Zhao, J., Goonetilleke, R.S., Foot measurements from threedimensional scans: A comparison and evaluation of different methods, Int J Ind Ergon, 2006, 36, 9, 789-807, https://doi. org/10.1016/j.ergon.2006.06.004.

19. Wang, M., Wang, X.A., Fan, Z., Zhang, S., Peng, C., Liu, Z., A 3D foot shape feature parameter measurement algorithm based on Kinect2, EURASIP J Image Vide, 2018, vol. 2018, 1, 1-12, https://doi.org/10.1186/ s13640-018-0368-5.

20. Jung, J., Lee, J.-Y., Jeong, Y., Kweon, I.S., Timeof-flight sensor calibration for a color and depth camera pair, IEEE Trans Pattern Anal Mach Intell, 2014, 37, 7, 1501-1513, https:// doi.org/10.1109/TPAMI.2014.2363827.

21. Zhang, C., Zhang Z., Calibration between depth and color sensors for commodity depth cameras, in Computer Vision and Machine Learning with RGB-D Sensors: Springer, 2014, pp. 47-64, https://doi.org/10.1007/978-3319-08651-4_3.

(C) 2020 by the author(s). Published by INCDTP-ICPI, Bucharest, RO. This is an open access article distributed under the terms and conditions of the Creative Commons Attribution license (http://creativecommons.org/licenses/ by/4.0/). 